\title{
De effecten van vuurwerk op de publieke gezondheid
}

\author{
Linda Nieuwenhoven · René Stumpel
}

Published online: 20 September 2019

(c) The Author(s) 2019

In de berichtgeving over oudjaarsavond wordt vaak gesproken over een rustige jaarwisseling. Vanuit het oogpunt van de publieke gezondheid is deze constatering onjuist. Elk jaar worden honderden mensen behandeld voor vuurwerkletsel. Bovendien blijven andere negatieve gevolgen van vuurwerk op de publieke gezondheid (gehoorschade, fijnstof en milieu, overlast) in het huidige debat over de (on)wenselijkheid van vuurwerk onderbelicht. Dit leidt tot een onderschatting van de negatieve effecten van vuurwerk. Door een overzicht te geven van de verschillende gezondheidseffecten van vuurwerk, wil dit artikel het debat verdiepen.

\section{Letsel}

Al geruime tijd brengt VeiligheidNL in kaart hoeveel mensen er elke jaarwisseling voor letsel door vuurwerk worden behandeld op de spoedeisende hulp (SEH; fig. 1; [1]). Het aantal slachtoffers verschilt zeer van jaar tot jaar. Gemiddeld gaat het om bijna 650 mensen. De afgelopen paar jaar is er wel een dalende trend te zien in het aantal SEH-slachtoffers. De beperking van de afsteektijden op oudjaarsdag van 10:00 naar 18:00 uur vanaf de jaarwisseling 2014/2015 heeft hier mogelijk aan bijgedragen.

Mensen met minder ernstige verwondingen komen bij de huisartsenpost (HAP) terecht. Deze cijfers worden sinds twee jaar geregistreerd, maar blijven in de media onderbelicht. Bij de jaarwisseling van 2018/2019 ging het om achthonderd HAP-behandelingen [1]. Als de SEH- en HAP-cijfers van afgelopen

\footnotetext{
L. Nieuwenhoven $(\varangle)$

GGD Flevoland, Lelystad, Nederland

1.nieuwenhoven@ggdflevoland.nl

R. Stumpel

GGD Gooi en Vechtstreek, Bussum, Nederland
}

jaarwisseling worden opgeteld, is er sprake van een stijging in het aantal slachtoffers ten opzichte van het jaar ervoor.

De meest voorkomende vuurwerkletsels zijn brandwonden en oogletsels. Gemiddeld wordt een op de acht vuurwerkslachtoffers voor behandeling in het ziekenhuis opgenomen en is er één vuurwerkdode per jaar te betreuren. Ongeveer de helft van de slachtoffers is omstander of voorbijganger, en raakte dus gewond door vuurwerk dat een ander heeft afgestoken. Mensen die vuurwerk afsteken nemen dus niet alleen een risico voor zichzelf. Driekwart van alle letsels werd veroorzaakt door legaal vuurwerk [1].

De slachtoffers zijn niet gelijkelijk verdeeld over de leeftijden. Bijna de helft van de slachtoffers is jonger dan twintig jaar, hoewel deze groep het vuurwerk maar in een derde van de gevallen afsteekt. Negen procent van alle slachtoffers is jonger dan tien jaar, en $21 \%$ is tussen de tien en veertien jaar [1]. Het aantal jeugdige slachtoffers is opvallend. De wet verbiedt namelijk de verkoop of het 'anderszins ter beschikking stellen' van bepaald vuurwerk aan jeugdigen. Sterretjes, abusievelijk gezien als kindervuurwerk bij uitstek, vallen onder vuurwerkcategorie F1 en mogen daarom pas vanaf twaalf jaar worden afgestoken. Categorie F2 (de meeste rotjes en fonteinen) is toegestaan vanaf zestien jaar en categorie F3 (veel vuurpijlen en grote sierpotten) vanaf achttien jaar. In de praktijk komt deze wet neer op een afsteekverbod van het meeste vuurwerk voor (jonge) kinderen. De leeftijdsverdeling van de letselcijfers laat zien dat men het met dit verbod niet zo nauw neemt. Het feit dat voorlichtingsprogramma's over het afsteken van vuurwerk zich op basisschoolkinderen richten, sluit wellicht aan bij de praktijk, maar niet bij de wet.

Vuurwerkletsel brengt kosten met zich mee. Naast de directe medische kosten en het ziekteverzuim zijn er ook andere (maatschappelijke) kosten, zoals (blij- 
Figuur 1 Aantal slachtoffers dat voor letsel door vuurwerk op de SEH werd behandeld [1]

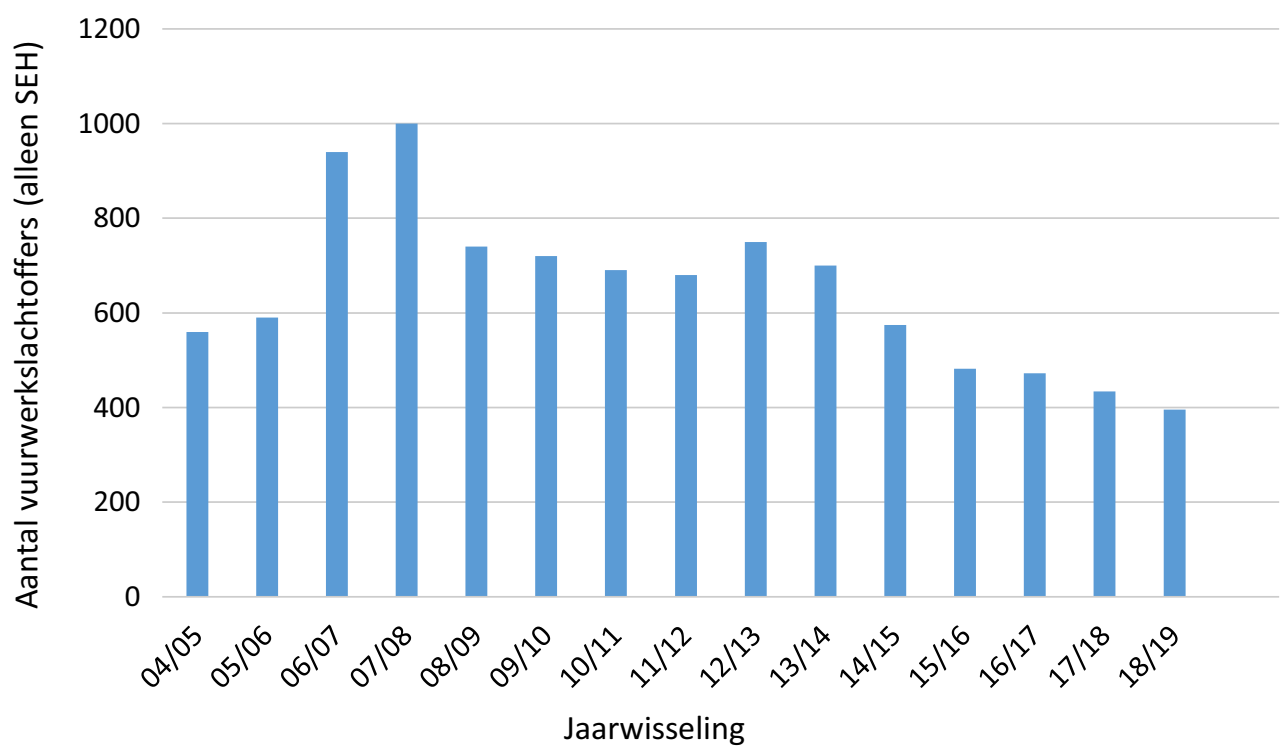

vende) arbeidsongeschiktheid, en immateriële kosten, zoals het verlies van levensjaren en kwaliteit van leven. De schaarse schattingen over de cumulatieve kosten lopen in de miljoenen [2].

\section{Gehoorschade}

Gehoorschade door vuurwerk is niet meegenomen in de bovengenoemde letselincidentie. Vaak komt gehoorschade namelijk pas later aan het licht, als mensen bij aanhoudende klachten de huisarts opzoeken. Bij (geh)oorschade kan er sprake zijn van gehoorverlies, tinnitus (oorsuizen) of gesprongen trommelvliezen.

De geluidsnorm voor vuurwerk is in Nederland $120 \mathrm{~dB}$ (piekmeting). Deze norm is gebaseerd op het aanhouden van de voorgeschreven veiligheidsafstand. Categorie F2-vuurwerk mag bijvoorbeeld $120 \mathrm{~dB}$ produceren op 8 meter afstand, terwijl categorie F3vuurwerk dat op 15 meter afstand mag. Als de afstand kleiner is dan is voorgeschreven, is de geluidsbelasting (en daarmee de kans op gehoorschade) groter. Dit kan gebeuren als het vuurwerk eerder afgaat dan verwacht, niet volgens het voorschrift wordt afgestoken of als het bij een omstander terechtkomt. Vaker nog biedt de fysieke omgeving (straat in de bebouwde kom met voorbijgangers) eenvoudigweg onvoldoende ruimte om de veiligheidsafstand in acht te nemen. Illegaal vuurwerk voldoet mogelijk helemaal niet aan de geluidsnorm.

Mensen hebben zelf niet altijd door dat het vuurwerk schadelijk luid is. Omdat de neurale verwerkingstijd soms langer duurt dan de knal zelf, neemt men kortdurende knallen als minder luid waar dan ze werkelijk zijn. Dit leidt tot een onderschatting van de risico's. Een ander probleem vormt het aantal knallen. Bij herhaaldelijke knallen is de kans op gehoorschade groter. Als tijdens de jaarwisseling veel mensen tegelijkertijd vuurwerk afsteken, is er dus een risico op gehoorschade doordat er herhaaldelijk geknald wordt; óók als deze knallen binnen de geluidsnorm zijn en de op het vuurwerk vermelde veiligheidsafstand in acht wordt genomen.

Milieu Centraal heeft berekend dat er in Nederland elke jaarwisseling naar schatting tussen de achten zestienhonderd mensen blijvende gehoorschade oplopen door vuurwerk (e-mail Milieu Centraal, augustus 2018). Een grootschalig Duits onderzoek naar het aantal behandelingen van gehoorproblemen door vuurwerk vond een gemiddelde incidentie van een op de tienduizend inwoners [3]. Bij jongeren was de incidentie drie keer zo hoog, en mannen waren drie keer zo vaak getroffen als vrouwen. De hoogste incidentie werd gevonden bij negentien jaar oude mannen: een op de duizend bezocht die jaarwisseling een arts vanwege gehoorschade door vuurwerk! Een groep die niet in deze cijfers is opgenomen betreft de mensen met gehoorschade die geen arts hebben opgezocht. Een verhoging van de gehoordrempel, bijvoorbeeld door verlies van hoge tonen, hoeft men bovendien niet meteen op te merken. Een onderschatting bij vooral kinderen en jongeren lijkt daarom aannemelijk. Deze cijfers wijzen op een gigantisch publiekegezondheidsrisico [3].

\section{Fijnstof en milieu}

Het afsteken van vuurwerk rond oudjaar zorgt voor een enorme piekbelasting in fijnstof. Afhankelijk van de weersomstandigheden kan de concentratie fijnstof zo'n veertig keer hoger zijn dan op een normale dag, waardoor de luchtkwaliteit soms zeer slecht is. Dit speelt voornamelijk in dichtbevolkte steden, waar vuurwerk geconcentreerd wordt afgestoken en het fijnstof door dichte bebouwing minder snel verwaait.

Fijnstof heeft nadelige gezondheidseffecten. Er is geen grens waaronder negatieve gezondheidseffecten door fijnstof niet optreden. Fijnstof heeft een nade- 
lig effect op hart- en bloedvaten en de luchtwegen, ook bij blootstelling op de korte termijn. Bij een verhoogde fijnstofbelasting is er een toename van het aantal ziekenhuisopnamen en eerstehulpbezoeken te zien. Ook neemt de onmiddellijke sterftekans toe. Een extra risico lopen mensen met long- en hartziekten, met astma of COPD, zwangeren, kleine kinderen, ouderen en mensen met acute luchtweginfecties [4].

Problematisch is dat onderzoek naar de kortetermijneffecten van fijnstof uitgaat van blootstelling van minimaal een dag tot een week. De fijnstofbelasting door vuurwerk is veel korter, maar ook extreem hoog. Door deze korte blootstellingsduur is het lastig te onderzoeken welk gezondheidseffect ervan uitgaat, al is een schadelijk effect aannemelijk. De directe relatie tussen fijnstof door vuurwerk en gezondheidseffecten is echter beperkt onderzocht - meer onderzoek is nodig.

Ook de samenstelling van het fijnstof afkomstig van vuurwerk is mogelijk van belang. Deze is anders dan bijvoorbeeld die van verkeer of houtrook. Met vuurwerk worden er veel chemicaliën en giftige metalen de lucht in geschoten, zoals barium, koper en aluminium. Deze deeltjes kunnen nog dagen of weken in de lucht blijven zweven en worden zo ingeademd. Omdat de blootstellingsduur beperkt is, zal het inademen van deze stoffen niet leiden tot een acute vergiftiging. Wat de precieze gezondheidseffecten wel zijn, is nauwelijks onderzocht, al zijn er (buiten de vuurwerkcontext) onderzoeken die de negatieve gezondheidseffecten van het inademen van deze stoffen aantonen [5].

De deeltjes kunnen ook neerslaan in de bodem, het riool en het oppervlaktewater, en zo leiden tot bodemen watervervuiling. Ze dragen bij aan de ophoping van zware metalen in het milieu. Het CBS et al. hebben berekend dat vuurwerkemissies hier voor sommige stoffen een groot aandeel in hebben: barium en strontium in het milieu komen voor $100 \%$ van vuurwerk; bij koper is dit rond 30\% [6]. Wanneer zware metalen in hoge concentraties in het milieu voorkomen, kunnen ze een negatief effect hebben op de gezondheid. Of en in welke mate vuurwerkemissies via deze route negatieve gezondheidseffecten veroorzaken, is onbekend. Dit geldt ook voor andere stoffen uit vuurwerk, zoals perchloraat. Een minder bekend en zeldzaam gezondheidseffect van vuurwerk betreft vergiftigingen door het eten van vuurwerk door kinderen of huisdieren.

\section{Overlast en stress}

Bijna vier op de vijf Nederlanders zegt af en toe, meestal of altijd overlast van vuurwerk rond de jaarwisseling te hebben. Dit aantal neemt de afgelopen jaren toe. Mensen die overlast ervaren, doen hiervan doorgaans geen melding: $83 \%$ laat dit achterwege [7]. Het aantal meldingen mag daarom niet als indicatie worden genomen voor de ervaren overlast.
Naast overlast kan er ook sprake zijn van stress en gevoelens van onveiligheid. Behalve harde knallen spelen hierbij ook angst voor lichamelijk letsel en het risico op materiële schade een rol. Ruim de helft van de Nederlanders is bang voor vuurwerk dat vlakbij hen wordt afgestoken. De angst heeft een grote impact: vier op de tien inwoners durven rond oudjaar niet goed de straat op vanwege vuurwerk dat wordt afgestoken [7].

Een aantal risicogroepen heeft een grotere kans op een stress- of angstreactie als gevolg van vuurwerk. Dit betreft ouderen, visueel gehandicapten, mensen met autisme of PTSS, of mensen die een oorlog hebben meegemaakt. In de weken rond de jaarwisseling moeten mensen met assistentiehonden hun dagelijks handelen aanpassen vanwege het vuurwerk en de angsten schrikreactie van hun honden.

\section{Vuurwerk is een probleem voor de publieke gezondheid}

Vanuit het oogpunt van de publieke gezondheid is het afsteken van consumentenvuurwerk niet te verantwoorden. Feitelijk komt de wetgeving erop neer dat het leken wordt toegestaan om explosieven af te steken onder soms zeer ongunstige omstandigheden (veel mensen op straat, alcoholgebruik, groepsgedrag, vermoeidheid, duisternis). Het is naïef om te denken dat dit, zelfs in het meest ideale geval, niet tot aanzienlijke gezondheidsschade zou leiden. Maatregelen om het risico op gezondheidsschade te verkleinen (verplichting van een afschietbuis voor vuurpijlen, gratis verstrekking van vuurwerkbrillen, voorlichting, enzovoort) sorteren wellicht enig effect, maar staan of vallen bij de bereidheid van mensen om ervan gebruik te maken. Bovendien blijkt uit de praktijk dat er te veel mensen zijn voor wie een verantwoorde omgang met vuurwerk niet haalbaar is.

Niet voor niets riep de Onderzoeksraad voor Veiligheid het kabinet op tot een verbod op knalvuurwerk en vuurpijlen [2]. Met restrictieve vuurwerkwetgeving kan namelijk wél veel schade worden voorkomen [8]. Deze zomer besloot het kabinet slechts tot een verbod op zwaar vuurwerk, waarmee het het advies van de Onderzoeksraad negeerde. De verantwoordelijkheid voor een totaalverbod komt bij gemeenten te liggen. Dit wijst erop dat de urgentie nog onvoldoende wordt gevoeld. Wisse et al. stelden dat het 'de verantwoordelijkheid is van de medische gemeenschap om gegevens over de gezondheidsrisico's van consumentenvuurwerk te verstrekken om de lopende discussie over vuurwerkwetgeving met evidence-based argumenten te voeden' [8, p. 7]. Met dit artikel willen we daar vanuit de publieke gezondheid een bijdrage aan leveren.

Een infographic met een overzicht van in bovenstaand artikel beschreven publieke gezondheidseffecten van vuurwerk is te downloaden via GGD GHOR Nederland. 
Open Access This article is distributed under the terms of the Creative Commons Attribution 4.0 International License (http://creativecommons.org/licenses/by/4.0/), which permits unrestricted use, distribution, and reproduction in any medium, provided you give appropriate credit to the original author(s) and the source, provide a link to the Creative Commons license, and indicate if changes were made.

\section{Literatuur}

1. Valkenberg H, Nijman S. Ongevallen met vuurwerk. Jaarwisseling 2018-2019. Amsterdam: Veiligheid NL; 2019.

2. Onderzoeksraad voor Veiligheid. Veiligheidsrisico's jaarwisseling. Den Haag: Onderzoeksraad voor Veiligheid; 2017.
3. Plontke S, Dietz K, Pfeffer C, Zenner H-P. The incidence of acoustic trauma due to New Year's firecrackers. Eur Arch Otorhinolaryngol. 2002;259(5):247-52.

4. Gezondheidsraad. Gezondheidswinst door schonerelucht. Den Haag: Gezondheidsraad; 2018.

5. Gouder C, Montefort S. Potential impact of fireworks on respiratoryhealth. Lung India. 2014;31(4):375-9.

6. CBS, PBL, RIVM, WUR. Luchtverontreiniging tijdens de jaarwisseling, 1994-2019. www.clo.nl, Den Haag: Centraal Bureau voor de Statistiek; 2019. Geraadpleegd op3 juli2019.

7. I\&O Research. Peiling vuurwerk en jaarwisseling 2018. Enschede: I\&O Research;2018.

8. Wisse RPL, Bijlsma WR, Stilma JS. Ocular firework trauma: a systematic review on incidence, severity, outcome and prevention. BrJOphthalmol. 2010;94(12):1586-91. 